\title{
First report of Coccinellid (Coleoptera: Coccinellidae) species found on Citrus orchards from the Central-West region of Santa Catarina, Brazil
}

\author{
R. D. B. Ducatti * (D), S. P. Tironi ${ }^{a}$ (D), S. Mariano-da-Silva ${ }^{a}$ (D), A. L. Radünz ${ }^{a}$ (D) and \\ M. A. Tramontin ${ }^{a}$ \\ a Departamento de Agronomia, Universidade Federal da Fronteira Sul - UFFS, Rodovia SC484, Km 02, \\ Bairro Fronteira Sul, CEP 89815899, Chapecó, SC, Brasil \\ *e-mail: rafaelducatti1007@gmail.com
}

Received: October 18, 2018 - Accepted: February 18, 2019 - Distributed: May 31, 2020

Coccinellids (Coleoptera: Coccinellidae), commonly known as lady beetles, ladybirds or labybugs, include more than six thousand identified species around the world, placed in 360 different genera and 42 tribes (Nedved and Kovar, 2012; Zazycki et al., 2015). For Brazil, according to Almeida et al. (2018) this family is represented by 667 species allocated in 96 genera. Coccinellids are round- to oval-bodied insects with a size ranging from 0.8 to $18 \mathrm{~mm}$. Their feeding habit varies according to the tribe they are placed. These insects are considered, by some authors (Hodek and Evans, 2012; Ducatti et al., 2017), as voracious predators and perhaps one of the more important families within the Order Coleoptera due to their predatory and economic importance. Coccinellids have been found feeding on insects of the Order Hemiptera (aphids, scales and whiteflies), eggs of the Order Lepidoptera (Lima et al., 2018), plants (Szawaryn et al., 2015), pollen, nectar, fungi, thrips (Hodek and Evans, 2012; Alvim et al., 2016), members of the family Chrysomelidae (Roberts, 2016), of the Order Hymenoptera (Majerus et al., 2007) and on members of the family Coccinellidae through cannibalism and intraguild predation (Ducatti et al., 2017).

Within this perspective, this study aimed at investigating the species of coccinellids present in organic and conventional citrus orchards located in the Central-west region of Santa Catarina, Brazil, and report differences on the diversity, evenness, abundance and richness between the studied areas.

The selected orchards had a similar size ( 4.0 hectares), altitude $(580 \mathrm{~m})$, were separated by a linear distance of $25 \mathrm{~km}$ and farmed with Citrus sinensis (L.) Osbeck cv. Valência. Samplings were carried out every 14 days, between March $13^{\text {th }}$ and June $19^{\text {th }}, 2016$ following the methodologies described by Colunga-Garcia et al. (1997) and Udayagiri et al. (1997). A total of seven cards were used by each area in each sampling date, totaling 49 cards per area. Coccinellids were removed from the cards using paint thinner solvent, placed in Eppendor $f^{\circledR}$, added with citronella oil (10\%) and sent to the Universidade Federal do Paraná to be identified. Statistical analyses were performed using the statistical program RStudio $^{\circ}$ version 1.0.136.

A total of 291 coccinellids placed in nine different tribes were sampled and identified. An amount of $48.80 \%$ were identified to the taxon of species, $14.43 \%$ to the taxon of genus and $36.77 \%$ were identified up to their tribe. Individuals identified only by the tribe, were divided according to their morphological characteristics and placed in groups dominated sp.1, sp.2 and sp.3 (Table 1).

The organic orchard presented $54.29 \%$ of all the specimens sampled and had a richness and evenness $16.67 \%$ and $11.36 \%$ greater than the conventional orchard, respectively. Nevertheless, both orchards were statistically similar as for their diversity $(P=0.5694)$.

Pentilia egena Mulsant, Cycloneda sanguinea Linnaeus, both native to Brazil, and individuals allocated in the tribe Diomini were the most abundant species in both farming systems in this study (Table 1). It has been reported that the main aphid-fed coccinellids for citrus in the region of Taiúva-SP, Brazil, were individuals belonging to the genus Diomus sp. (70.95\%), and the species C. sanguinea (18.83\%) (Guerreiro et al., 2005), which can prey a daily average of 233.8 and 209 aphids (Aphis craccivora) by female and male adults, respectively (Solano et al., 2016).

For the state of Rio de Janeiro, the most common species of coccinellids sampled, in citrus, was $P$. egena, which was present in 10 of the 11 studied cities. Pentilia egena is characterized by being one of the more important predator species of coccinellids found in citrus orchards, mainly due to its high level of predation on scale insects. The daily average consumption of Chrysomphalus ficus Ashmed (Hemiptera: Diaspididae) by P. egena is of 69.21, 54.40 and 15.61 individuals in their $1^{\text {st }}, 2^{\text {nd }}$ nymph and adult development stages, respectively (Guerreiro et al., 2003).

About $98 \%$ of all sampled specimens identified in this study are allocated in aphid-, scale-fed tribes, which may be beneficial as for the biological control coccinellids play in the studied areas (Table 2).

Another species found in this study, and reported worldwide was Harmonia axyridis, a species native from Asia and highly voracious (Milléo et al., 2008; Ducatti et al., 2017). This species was first recorded in Brazil in 2002, in the state of Paraná, probably following its introduction in the province of Mendonza, Argentina in the end of the 90's (Milléo et al., 2008). This is the first time H. axyridis is recorded for the city of Chapecó-SC. 
Table 1. Tribe, species and abundance (\%) of coccinellids sampled in both, organic and conventional, citrus orchards located in the Central-west region of Santa Catarina.

\begin{tabular}{|c|c|c|c|c|c|}
\hline \multirow{2}{*}{ Tribe } & \multirow{2}{*}{ Species } & \multicolumn{2}{|c|}{ Conventional system } & \multicolumn{2}{|c|}{ Organic system } \\
\hline & & Quantity & $(\%)$ & Quantity & $(\%)$ \\
\hline Azyini & Azya luteipes (Mulsant, 1850) & 1 & 0.75 & 0 & 0.00 \\
\hline Chilocorini & Exochomus orbiculus (Weise, 1893) & 2 & 1.50 & 3 & 1.90 \\
\hline Coccinellini & Cycloneda pulchella (Klug, 1829) & 0 & 0.00 & 1 & 0.63 \\
\hline Coccinellini & Cycloneda sanguinea (Linnaeus, 1763) & 23 & 17.29 & 15 & 9.49 \\
\hline Coccinellini & Harmonia axyridis (Pallas, 1773) & 1 & 0.75 & 0 & 0.00 \\
\hline Coccinellini & Cycloneda sp & 0 & 0.00 & 1 & 0.63 \\
\hline Cryptognathini & Calloeneis signata (Korschefsky, 1935) & 1 & 0.75 & 15 & 9.49 \\
\hline Diomini & sp. 1 & 0 & 0.00 & 27 & 17.09 \\
\hline Diomini & sp. 2 & 40 & 30.08 & 4 & 2.53 \\
\hline Diomini & sp. 3 & 1 & 0.75 & 5 & 3.16 \\
\hline Diomini & Diomus sp. & 0 & 0.00 & 24 & 15.19 \\
\hline Chnoodini & Exoplectra sp. & 2 & 1.50 & 0 & 0.00 \\
\hline Coccinellini & Psyllobora distinguenda (Crotch, 1874) & 2 & 1.50 & 0 & 0.00 \\
\hline Coccinellini & Psyllobora gratiosa (Mader, 1958) & 1 & 0.75 & 5 & 3.16 \\
\hline Hyperaspidini & Hyperaspis matronata (Mulsant, 1853) & 0 & 0.00 & 1 & 0.63 \\
\hline Hyperaspidini & Tenuisvalvae rosariensis Gonzáles 2010 & 6 & 4.51 & 1 & 0.63 \\
\hline Ortaliini & Zenoria serva (Gordon, 1971) & 0 & 0.00 & 3 & 1.90 \\
\hline Ortaliini & Zenoria sp. & 0 & 0.00 & 1 & 0.63 \\
\hline Cryptognathini & Pentilia egena (Mulsant, 1850) & 25 & 18.80 & 36 & 22.78 \\
\hline Cryptognathini & Pentilia sp. & 3 & 2.26 & 11 & 6.96 \\
\hline Scymnini & sp. 1 & 2 & 1.50 & 2 & 1.27 \\
\hline Scymnini & sp. 2 & 23 & 17.29 & 3 & 1.90 \\
\hline Total & & 133 & 100.00 & 158 & 100.00 \\
\hline
\end{tabular}

Table 2. Feeding habits and abundance of Coccinellidae tribes identified in citrus orchards from the Central-west region of Santa Catarina.

\begin{tabular}{lcl}
\hline \multicolumn{1}{c}{ Tribe } & Abundance (\%) & \multicolumn{1}{c}{ Feeding habit $^{(\mathbf{1})}$} \\
\hline Azyini & 0.34 & Scale insects, aphids \\
Chilocorini & 1.72 & Scale insects, aphids \\
Chnoodini & 0.69 & Inga adulis nectar, white-fly, scale insects, aphids \\
Coccinellini $^{(2)}$ & 16.84 & Chrysomelidae, scale insects, Psyllidae, aphids, fungi, ants \\
Cryptognathini & 31.27 & Scale insects, aphids, mites \\
Diomini & 34.71 & Scale insects \\
Hyperaspidini & 2.75 & Scale insects \\
Ortaliini & 1.37 & Psyllidae \\
Scymnini & 10.31 & Scale insects, white-fly, aphids \\
\hline${ }^{(1)}$ Compiled from Guerreiro et al. (2003), Hodek and Evans (2012), Alvim et al. (2016), Ducatti et al. (2017), Majerus et al. (2007) \\
and Lima et al. (2018). ${ }^{(2)}$ Species placed in the genera Psyllobora sp. are mycophagous (Hodek and Evans, 2012).
\end{tabular}

\section{Acknowledgements}

We would like to thank the personnel of the Laboratório de Sistemática e Bioecologia de Coleoptera (Insecta), Department of Zoology of the Universidade Federal do Paraná (UFPR) for helping us in the identification of the specimens.

\section{References}

ALMEIDA, L.M., SANTOS, P.B. and CASTRO-GUEDES, C.F., 2018 [viewed 18 October 2018]. Coccinellidae in Catálogo Taxonômico da Fauna do Brasil [online]. PNUD. Available from: http://fauna.jbrj.gov.br/fauna/faunadobrasil/121379
ALVIM, R.G., AGUIAR-MENEZES, E.L. and LIMA, A.F., 2016. Dissemination of Aleurocanthus woglumi in citrus plants, its natural enemies and new host plants in the state of Rio de Janeiro, Brazil. Ciência Rural, vol. 46, no. 11, pp. 1891-1897. http://dx.doi.org/10.1590/0103-8478cr20151101.

COLUNGA-GARCIA, M., GAGE, S.H. and LANDIS, D.A., 1997. Response of an assemblage of Coccinellidae (Coleoptera) to a diverse agricultural landscape. Environmental Entomology, vol. 26, no. 4, pp. 797-804. http://dx.doi.org/10.1093/ee/26.4.797.

DUCATTI, R.D.B., UGINE, T.A. and LOSEY, J., 2017. Interactions of the Asian Lady Beetle, Harmonia axyridis (Coleoptera: Coccinellidae), and the North American native Lady Beetle, Coccinella novemnotata (Coleoptera: Coccinellidae): Prospects for recovery post-decline. Environmental Entomology, 
vol. 46, no. 1, pp. 21-29. http://dx.doi.org/10.1093/ee/nvw153. PMid:28049630.

GUERREIRO, J.C., BUENO, P.R.R., FILHO BERTI, E. and BUSOLI, A.C., 2005. Ocorrência estacional das principais espécies de Coccinellidae predadores de Toxoptera citricida nos citros. Revista Científica Eletrônica de Agronomia, vol. 4, no. 7, pp. 1-14.

GUERREIRO, J.C., BUSOLI, A.C. and BERTI FILHO, E., 2003. Oviposition and predation of Pentilia egena Mulsant (Coleoptera: Coccinellidae) in response to temperature. Scientia Agrícola, vol. 60, no. 3, pp. 587-589. http://dx.doi.org/10.1590/ S0103-90162003000300026.

HODEK, I. and EVANS, E.W., 2012. Food relationships. In: H. F. HODEK, H. F. VANEMDEN and A. HONEK, eds. Ecology and behaviour of the Ladybird Beetles (Coccinellidae). United Kingdom: Wiley-Blackweel, pp. 141-274.

LIMA, M.S., MELO, J.W.S. and BARROS, R., 2018. Alternative food sources for the ladybird Brumoides foudrasii (Mulsant) (Coleoptera: Coccinellidae). Brazilian Journal of Biology $=$ Revista Brasileira de Biologia, vol. 78, no. 2, pp. 211-216. http://dx.doi. org/10.1590/1519-6984.02816. PMid:28793028.

MAJERUS, M.E.N., SLOGGETT, J.J., GODEAU, J.F. and HEMPTINNE, J.L., 2007. Interactions between ants and aphidophagous and coccidophagous ladybirds. Population Ecology, vol. 49, no. 1, pp. 15-27. http://dx.doi.org/10.1007/ s10144-006-0021-5.

MILLÉO, J., SOUZA, J.M.T., BARBOLA, I.F. and HUSCH, P.E., 2008. Harmonia axyridis em árvores frutíferas e impacto sobre outros coccinelídeos predadores. Pesquisa Agropecuária Brasileira, vol. 43, no. 4, pp. 537-540. http://dx.doi.org/10.1590/ S0100-204X2008000400013.
NEDVED, O. and KOVAR, I., 2012. Phylogeny and classification. In: H. F. HODEK, H. F. VANEMDEN and A. HONEK, eds. Ecology and Behaviour of the Ladybird Beetles (Coccinellidae). United Kingdom: Wiley-Blackweel,pp. 1-12. http://dx.doi. org/10.1002/9781118223208.ch1.

ROBERTS, D.E., 2016. Classical biological control of the cereal leaf beetle, Oulema melanopus (Coleoptera: Chrysomelidae), in Washington State and role of field insectaries, a review. Biocontrol Science and Technology, vol. 26, no. 7, pp. 877-893. http://dx.doi. org/10.1080/09583157.2016.1165794.

SOLANO, Y., DELGADO, N., MORALES, J. and VÁSQUEZ, C., 2016. Functional response of Cycloneda sanguinea (L.) (Coleoptera: Coccinellidae) to the black pea aphid, Aphis craccivora Koch (Hemiptera: Aphididae). Entomotrópica, vol. 31, pp. 311-318.

SZAWARYN, K., BOCAK, L., SLIPINSKI, A., ESCALONA, H.E. and TOMASZEWSKA, W., 2015. Phylogeny and evolution of phytophagous ladybird beetles (Coleoptera: Coccinellidae: Epilachnini), with recognition of new genera. Systematic Entomology, vol. 40, no. 3, pp. 547-569. http://dx.doi.org/10.1111/syen.12121.

UDAYAGIRI, S., MASON, C.E. and PESEK JUNIOR, J.D., 1997. Coleomegilla maculata, Coccinella septempunctata (Coleoptera: Coccinellidae), Chrysoperla carnea (Neuroptera: Chrysopidae), and Macrocentrus grandii (Hymenoptera: Braconidae) trapped on colored sticky traps in corn habitats. Environmental Entomology, vol. 26, no. 4, pp. 983-988. http://dx.doi.org/10.1093/ee/26.4.983.

ZAZYCKI, L.C.F., SEMEDO, R.E.S., SILVA, A., BISOGNIN, A.Z., BERNARDI, O., GARCIA, M.S. and NAVA, D.E., 2015. Biology and fertility life table of Eriopis connexa, Harmonia axyridis and Olla v-nigrum (Coleoptera: Coccinellidae). Brazilian Journal of Biology = Revista Brasileira de Biologia, vol. 75, no. 4, pp. 969-973. http://dx.doi.org/10.1590/1519-6984.03814. PMid:26675915. 